Journal of Applied Pharmaceutical Science Vol. 6 (08), pp. 122-126, August, 2016

Available online at http://www.japsonline.com

DOI: $10.7324 / J A P S .2016 .60819$

ISSN 2231-3354 (cc) BY-NC-SA

\title{
Comparative analysis of the composition of essential oils from the needles, twigs and berries of Juniperus chinensis L. in Korea
}

\author{
Kandhasamy Sowndhararajan, Min Seo, Songmun Kim* \\ Department of Biological Environment, Kangwon National University, Chuncheon 24341, Gangwon, Republic of Korea.
}

\begin{tabular}{|c|c|}
\hline ARTICLE INFO & ABSTRACT \\
\hline $\begin{array}{l}\text { Article history: } \\
\text { Received on: } 13 / 06 / 2016 \\
\text { Revised on: } 01 / 07 / 2016 \\
\text { Accepted on: } 26 / 07 / 2016 \\
\text { Available online: } 30 / 08 / 2016 \\
\end{array}$ & $\begin{array}{l}\text { The essential oil constituents from the needles, twigs and berries of Juniperus chinensis from Korea were } \\
\text { investigated by gas chromatography-mass spectrometry (GC-MS). The essential oils from the different plant } \\
\text { parts were obtained by steam distillation and the yields were } 0.34,0.11 \text { and } 0.12 \% \text { (v/w), respectively. The GC- } \\
\text { MS analysis revealed the identification of } 36 \text { different components from needles, twigs and berries, which were } \\
\text { mostly monoterpene hydrocarbons }(42.05-48.15 \%) \text { followed by oxygenated monoterpenes (28.53- }\end{array}$ \\
\hline $\begin{array}{l}\text { Key words: } \\
\text { Berry, Essential oil, Juniper, } \\
\text { Juniperus chinensis, Needle. }\end{array}$ & $\begin{array}{l}39.92 \%) \text {. Among the } 36 \text { components, } 17 \text { components were identified in all the three essential oils. The } \\
\text { components such as bornyl acetate }(2.85-20.70 \%) \text {, sabinene }(10.23-18.13 \%), \alpha \text {-pinene }(5.80-16.26 \%) \text {, } \\
\text { terpinen- } 4 \text {-ol }(5.98-31.10 \%) \text {, limonene }(3.98-6.96 \%), \beta \text {-pinene }(3.05-4.39 \%), \gamma \text {-terpinene }(2.24-8.36 \%) \text {, } \\
\alpha \text {-elemol }(1.74-4.77 \%) \text { and } \alpha \text {-cadinol }(2.49-3.39 \%) \text { were detected as the major components in the essential } \\
\text { oils from the three different parts of } J \text {. chinensis. The main differences between the three essential oils can be } \\
\text { referred to terpinen-4-ol and bornyl acetate. The essential oil of the berries contained the highest level of } \\
\text { terpinen-4-ol }(31.10 \%) \text { than needles }(7.51 \%) \text { and twigs }(5.98 \%) \text {. On the other hand, bornyl acetate content was } \\
\text { very less in berries }(2.85 \%) \text { when compared with twigs }(20.70 \%) \text { and needles }(16.43 \%) \text {. }\end{array}$ \\
\hline
\end{tabular}

\section{INTRODUCTION}

The genus Juniperus (Cupressaceae) comprises about 70 species of evergreen shrubs or trees, widely distributed in the Northern Hemisphere (Foudil-Cherif and Yassaa, 2012). The essential oils from the needles and berries of various Juniperus species have been used for cosmetic and therapeutical purposes in many centuries. Among them, Juniperus chinensis L. (Chinese juniper) is a well-known species in China, Korea, Japan, Myanmar and eastern parts of Russia (Jin et al., 2015).In the traditional medicine, J. chinensis has been used for the treatment of gout, rheumatism, diarrhea, and chronic tracheitis (Ali et al., 1996; Lee et al., 2009).Previous studies have reported that J. chinensis possesses antioxidant, anti-inflammatory, anti-obesity, antitumor, antimicrobial, acaricidal, and repellent

\footnotetext{
* Corresponding Author

Songmun Kim, Department of Biological Environment, Kangwon National University, Chuncheon 24341, Gangwon, Republic of Korea mail id:perfume@kangwon.ac.kr
}

activities (Ali et al., 1996; Lim et al., 2002; Kim et al., 2008; Lee et al., 2009; Carroll et al., 2011). Jin et al. (2015) studied the antimelanogenic activities of methanol extracts of $J$. chinensis and isolation of functional compounds such as cedrol and widdrol. This plant contains various bioactive components such as terpenes, lignins, and flavones (Lim et al., 2002). Several studies have reported the chemical composition of essential oils from the needles of $J$. chinensis. The results showed a variation in the chemical composition and concentration of major components (sabinene, bornyl acetate, $\alpha$-pinene, limonene and elemol) between the samples (Raina et al., 2005; Afsharypuor et al., 2007; Lee et al., 2009; Carroll et al., 2011; Kim et al., 2015). The essential oil composition and its contents are mainly influenced by geographical location, weather parameters, plant part and age of the plant (Dhouioui et al., 2016). To the best of our knowledge, there has been no previous study on the comparison of essential oil composition from the different plant parts of J. chinensis. Hence, the present study was carried out to investigate the composition of essential oils obtained by steam distillation from different plant organs (needles, twigs and berries) of J. chinensis. 


\section{MATERIALS AND METHODS}

\section{Plant material and extraction of essential oil}

The different parts such as needles, twigs and berries of J. chinensis (Fig. 1) were collected from Kangwon National University campus, Chuncheon, Republic of Korea during the month of July 2015. The plant was authenticated and deposited in the Herbarium, Daejin University, Pocheon, Gyeonggi-do, Republic of Korea with voucher number DJU- 20160869.

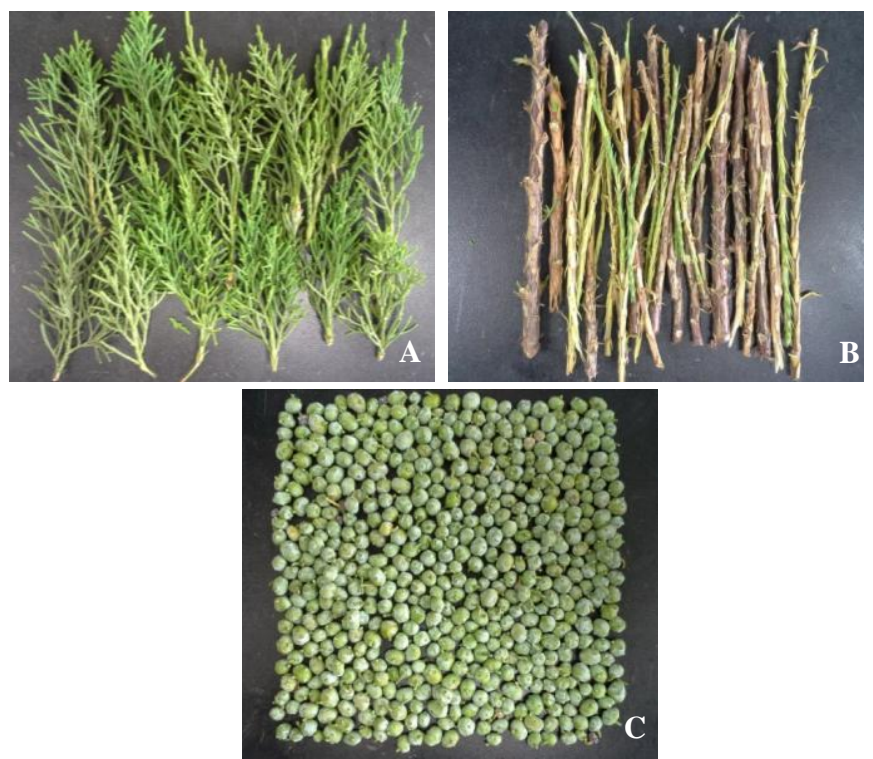

Fig. 1: The different plant parts of Juniperus chinensis. A, needles; B, twigs; C, berries.

\section{Extraction of essential oils}

The essential oil was separately extracted from the needles, twigs (without needles) and berries (unripe) by steam distillation (HanilLabTech., Republic of Korea) at $100{ }^{\circ} \mathrm{C}$ for 90 min (1 kg sample) using a Clevenger-type apparatus. The collected essential oils were dried with anhydrous sodium sulfate and stored under refrigeration $\left(4^{\circ} \mathrm{C}\right)$.

\section{Gas chromatography/mass spectrometry (GC/MS) analysis}

GC-MS analysis was performed with a Varian CP 3800 gas chromatography equipped with a VF-5 MS polydimethylsiloxane capillary column $(30 \times 0.25 \mathrm{~mm} \times 0.25 \mu \mathrm{m})$ and a Varian $1200 \mathrm{~L}$ mass detector (Varian, CA, USA). Helium was used as a carrier gas at the rate of $1 \mathrm{~mL} / \mathrm{min}$. Oven temperature was kept at $50^{\circ} \mathrm{C}$ for $5 \mathrm{~min}$ initially, and then raised with rate of $5^{\circ} \mathrm{C} / \mathrm{min}$ to $250^{\circ} \mathrm{C} / \mathrm{min}$. The injected volume of essential oil was $10 \mu \mathrm{L}$ with a split ratio of $1: 10$. The injector temperature was set at $250^{\circ} \mathrm{C}$. The mass spectra were recorded in the electrospray ionization mode at $70 \mathrm{eV}$ in a scan range of 50 $600 \mathrm{~m} / \mathrm{z}$. The components of essential oils were identified by comparing the retention indices of the GC peaks obtained using homologous series of n-alkanes $\left(\mathrm{C}_{8}-\mathrm{C}_{20}\right)$ with those reported in literature (Adams, 2007). The mass spectra of the peaks were also matched with standards reported in literature and National Institute of Standards and Technology (NIST, 3.0) library.

\section{RESULTS AND DISCUSSION}

The essential oil yields were $0.34 \%, 0.11 \%$ and $0.12 \%$ (v/w) for the needles, twigs and berries, respectively, and their compositions are presented in Table 1.The yield of essential oil from juniper needles $(0.34 \%, \mathrm{v} / \mathrm{w})$ was almost thrice that from twigs as well as berries. A total of 36 components were identified in the essential oils, accounting for $98.39 \%$ (needles), $98.18 \%$ (twigs) and $98.24 \%$ (berries) of the total compositions. Out of 36 components, 17 components were detected in all the three essential oils. From the results, qualitative and quantitative differences were observed in the composition of the essential oils obtained from different organs of $J$. chinensis. In the overall results, all the three essential oils showed a higher percentage of monoterpenes $(72.87$ - 88.07\%) than sesquiterpenes (9.29\% - 23.68\%) (Fig. 2). Although these three essential oils contained higher amount of monoterpenes, there were differences in composition between the detected components. Among the three essential oils, the essential oil from the berries contained the highest amount of monoterpene hydrocarbons $(48.15 \%)$ and oxygenated monoterpenes $(39.92 \%)$ than twigs (45.06 and 28.53, respectively) and needles (42.05 and $30.82 \%$, respectively). On the other hand, the amount of sesquiterpene hydrocarbons were found to be higher in the essential oils from the twigs $(15.16 \%)$ and needles $(7.37 \%)$ than berries $(0.57 \%)$ (Fig. 2).For oxygenated sesquiterpenes, the highest percentages were detected in needles (15.95\%), followed by berries $(8.52 \%)$ and twigs $(8.52 \%)$. Further, the three essential oils also contained a small amount oxygenated diterpenes $(0.88-$ $2.2 \%)$.

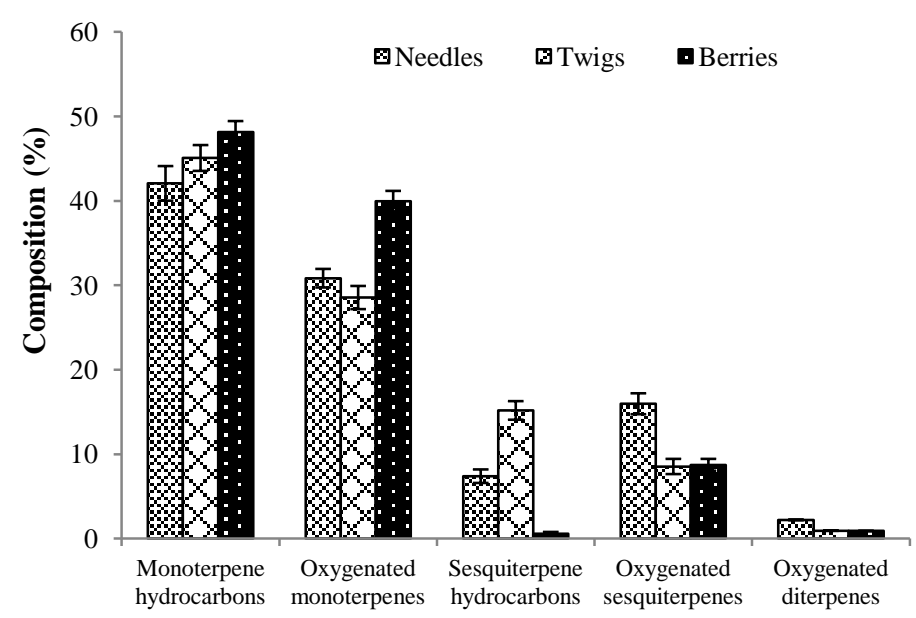

Chemical group

Fig. 2: Percentage concentration of different chemical groups in the essential oils from the needles, twigs and berries of Juniperus chinensis. Values are mean of three replicate determinations $(n=3) \pm$ standard deviation. 
Table 1: Essential oil composition from the needles, twigs and berries of Juniperus chinensis.

\begin{tabular}{|c|c|c|c|c|c|}
\hline \multirow{2}{*}{ No. ${ }^{a}$} & \multirow{2}{*}{ Components $^{\mathrm{b}}$} & \multirow{2}{*}{$\mathbf{R I}^{\mathbf{c}}$} & \multicolumn{3}{|c|}{ Area (\%) } \\
\hline & & & Needles & Twigs & Berries \\
\hline 1 & Tricyclene & 926 & $1.66 \pm 0.08$ & - & \\
\hline 2 & $\alpha$-Thujene & 930 & - & - & $0.86 \pm 0.04$ \\
\hline 3 & $\alpha$-Pinene & 939 & $5.80 \pm 0.19$ & $16.26 \pm 0.76$ & $6.88 \pm 0.46$ \\
\hline 4 & Camphene & 954 & $0.92 \pm 0.33$ & $0.78 \pm 0.15$ & $0.16 \pm 0.03$ \\
\hline 5 & Sabinene & 975 & $18.13 \pm 0.87$ & $10.23 \pm 1.01$ & $14.28 \pm 0.77$ \\
\hline 6 & $\beta$-pinene & 979 & $3.05 \pm 0.14$ & $3.72 \pm 0.34$ & $4.39 \pm 0.06$ \\
\hline 7 & 2-Carene & 1002 & $1.64 \pm 0.13$ & $1.30 \pm 0.22$ & - \\
\hline 8 & $\alpha$-Phellandrene & 1002 & - & - & $0.46 \pm 0.04$ \\
\hline 9 & 3-Carene & 1011 & - & $1.97 \pm 0.34$ & - \\
\hline 10 & $\alpha$-Terpinene & 1017 & - & - & $5.39 \pm 0.14$ \\
\hline 11 & o-Cymene & 1026 & - & - & $0.33 \pm 0.17$ \\
\hline 12 & Limonene & 1029 & $6.80 \pm 0.83$ & $6.96 \pm 0.13$ & $3.98 \pm 0.06$ \\
\hline 13 & $\gamma$-Terpinene & 1059 & $2.52 \pm 0.09$ & $2.24 \pm 0.30$ & $8.36 \pm 0.13$ \\
\hline 14 & Terpinolene & 1088 & $1.53 \pm 0.09$ & $1.60 \pm 0.13$ & $3.06 \pm 0.07$ \\
\hline 15 & Linalool & 1096 & $2.90 \pm 0.43$ & - & - \\
\hline 16 & $\beta$-Terpineol & 1140 & $1.34 \pm 0.07$ & - & $2.72 \pm 0.36$ \\
\hline 17 & Camphor & 1146 & $0.91 \pm 0.15$ & $0.66 \pm 0.08$ & - \\
\hline 18 & Camphene hydrate & 1149 & $0.85 \pm 0.08$ & - & - \\
\hline 19 & Borneol & 1169 & - & $0.55 \pm 0.05$ & - \\
\hline 20 & Terpinen-4-ol & 1177 & $7.51 \pm 0.24$ & $5.98 \pm 0.12$ & $31.10 \pm 0.21$ \\
\hline 21 & $\alpha$-Terpineol & 1188 & $0.88 \pm 0.30$ & $0.64 \pm 0.03$ & $2.32 \pm 0.07$ \\
\hline 22 & Piperitol & 1196 & - & - & $0.93 \pm 0.06$ \\
\hline 23 & Bornyl acetate & 1286 & $16.43 \pm 0.31$ & $20.70 \pm 0.87$ & $2.85 \pm 0.21$ \\
\hline 24 & Caryophyllene & 1419 & $0.24 \pm 0.01$ & $2.55 \pm 0.43$ & - \\
\hline 25 & $\alpha$-Humulene & 1454 & $1.59 \pm 0.10$ & $9.90 \pm 1.08$ & - \\
\hline 26 & $\alpha$-Muurolene & 1500 & $1.65 \pm 0.11$ & - & - \\
\hline 27 & $\gamma$-Cadinene & 1513 & $3.89 \pm 0.14$ & $2.71 \pm 0.28$ & $0.57 \pm 0.02$ \\
\hline 28 & $\alpha$-Elemol & 1549 & $4.77 \pm 0.53$ & $1.74 \pm 0.06$ & $3.79 \pm 0.19$ \\
\hline 29 & Germacrene D-4-ol & 1575 & - & $1.17 \pm 0.27$ & - \\
\hline 30 & Ledol & 1602 & $3.65 \pm 0.50$ & - & - \\
\hline 31 & Humulene epoxide II & 1608 & $1.51 \pm 0.12$ & $0.93 \pm 0.06$ & $1.01 \pm 0.05$ \\
\hline 32 & T-Cadinol & 1640 & $2.63 \pm 0.06$ & $0.70 \pm 0.03$ & $0.53 \pm 0.06$ \\
\hline 33 & $\alpha$-Muurolol & 1646 & - & $0.63 \pm 0.06$ & $0.90 \pm 0.08$ \\
\hline 34 & $\alpha$-Cadinol & 1654 & $3.39 \pm 0.45$ & $3.35 \pm 0.52$ & $2.49 \pm 0.23$ \\
\hline 35 & Epimanool & 2060 & $1.37 \pm 0.26$ & $0.56 \pm 0.02$ & $0.34 \pm 0.14$ \\
\hline 36 & Abietal & 2313 & $0.83 \pm 0.14$ & $0.35 \pm 0.04$ & $0.54 \pm 0.05$ \\
\hline & Total Identified & & $98.39 \pm 0.06$ & $98.18 \pm 0.24$ & $98.24 \pm 0.29$ \\
\hline & Oil yield (v/w) & & 0.34 & 0.11 & 0.12 \\
\hline
\end{tabular}

${ }^{a}$ In order of elution on VF-5ms; ${ }^{b}$ Components identified based on mass spectra and retention indices; ${ }^{c}$ RI, Retention indices reported in the literature. Values are mean of three replicate determinations $(n=3) \pm$ standard deviation.

The components such as bornyl acetate $(2.85-20.70 \%)$, sabinene $(10.23$ - 18.13\%), $\alpha$-pinene $(5.80$ - 16.26), terpinen-4-ol $(5.98-31.10)$, limonene $(3.98-6.96 \%)$, $\beta$-pinene $(3.05-4.39 \%)$, $\gamma$-terpinene $(2.24-8.36 \%)$, $\alpha$-elemol $(1.74-4.77 \%)$ and $\alpha$-cadinol $(2.49-3.39 \%)$ were detected as the major components in the essential oils from the three different parts of J. chinensis. The major differences between the three essential oils were related to terpinen-4-ol and bornyl acetate. The essential oil of the berries contained the highest level of terpinen-4-ol (31.10\%) than needles $(7.51 \%)$ and twigs $(5.98 \%)$. In regards tobornyl acetate, the highest percentage was found in the twigs $(20.70 \%)$, followed by the needles $(16.43 \%)$ and considerably lowest percentage in the berries $(2.85 \%)$. The essential oil of twigs registered the highest amount of $\alpha$-pinene $(16.26 \%)$ than berries $(6.88 \%)$ and needles $(5.80 \%)$. The twigs also contained a higher amount of $\alpha$-humulene $(9.90 \%)$ than needles $(1.59 \%)$. Whereas, sabinene content was found to be higher in the essential oil of needles $(18.13 \%)$ followed by berries (14.28\%) and twigs (10.23\%). In addition, a considerable amount of $\alpha$-terpinene $(5.39 \%)$ was found only in the essential oil of berries. Among the three essential oils, ledol
$(3.65 \%)$ and linalool $(2.90 \%)$ were detected only in the essential oil of needles. The major components from the different parts of $J$. chinensis have also been identified as important bioactive components in the essential oils of various plant species. Among the major components, bornyl acetate has various pharmacological properties including depressing spasm, sedative, antidiarrheal, analgesic, anti-inflammatory and anti-abortive properties (Wang et al., 2011; Chen et al., 2014). Terpinen-4-ol has been reported to have several pharmacological activities such as anti-inflammatory, antimicrobial and vascular muscle relaxation (Hart et al., 2000; Loughlin et al., 2008; Maia-Joca et al., 2014). $\alpha$-Pinene is a broadspectrum antibiotic and has anti-inflammatory, hypoglycemic, sedative, antioxidant, antiulcer and inhibition of acetylcholinesterase enzyme activities (Pinheiro et al., 2015). Limonene is used as an additive in food products, cosmetics and perfumes (Sowndhararajan et al., 2015). It has antitumor and anxietic effects and aroma of this compound enhances the mental conditions of human (Crowell and Gould, 1994; Heuberger et al., 2001; Lima et al., 2013). Another major component, sabinene possesses antioxidant, antifungal and anti-inflammatory properties 
(Kohzakiet al., 2009; Valente et al., 2013).

Previously, several authors reported that the essential oil composition from the needles of J. chinensis. Kim et al. (2015) studied the essential oil composition from the leaves of five Juniperus chinensis varieties in Korea (J. chinensis L., J. chinensis var. globosa, J. chinensis var. horizontalis, J. chinensis var. kaizuka, J. chinensis var. sargentii) and the essential oils mainly consisted of monoterpenes with bornyl acetate $(15.26-44.31 \%)$ and sabinene $(3.61-28.35 \%)$ as major components. The results of the present study also indicated that sabinene $(18.13 \%)$ and bornyl acetate $(16.43 \%)$ were detected as major components in the essential oil of needles. Further, the twigs (without needles) also contained $10.23 \%$ of sabinene and $20.70 \%$ of bornyl acetate in addition to $16.26 \%$ of $\alpha$-pinene (Table 1 ). Similarly, Raina et al. (2005), Afsharypuora et al. (2007) and Lee et al. (2009) reported that sabinene $(19.80,18.03$ and $21.1 \%$, respectively) and bornyl acetate $(17.50,26.10$ and $19.5 \%$ respectively) were detected as major components in the essential oil from the needles of $J$. chinensis L.

Similar to the present study, Hafi et al. (2015) studied the chemical composition from berries, leaves and twigs of Lebanese $J$. excelsa. A total of 30 constituents were identified in the essential oils from the leaves, cones and twigs of J. excelsa and the main component in these oils was $\alpha$-pinene. Further, the amount of major constituents in the different plant organs varied significantly. Angioni et al. (2003) investigated the chemical composition of the essential oils from the ripe and unripe berries and leaves of J. oxycedrus L. ssp. oxycedrus, J. phoenicea ssp. turbinata and $J$. communis ssp. communis and observed both qualitative and quantitative differences between species and between different plant parts. $\alpha$-Pinene, $\beta$-pinene, $\delta$-3-carene, sabinene, myrcene, $\beta$-phellandrene, limonene, and D-germacrene were registered as the major components in these essential oils. In addition, the percentage of monoterpenes was higher in the ripe $(95 \%)$ and unripe berries $(94.83 \%)$ than in the leaves $(87.78 \%)$. In Lithuania, the essential oils from the needles and ripe berries of $J$. communis var. communis mainly contained $42.4-67.4 \%$ of $\alpha$ pinene (Butkieneet al., 2007).

The essential oil of $J$. communis L. berries from Bulgaria is largely consisted of monoterpene hydrocarbons such as $\alpha$-pinene $(51.4 \%)$, myrcene $(8.3 \%)$, sabinene $(5.8 \%)$, limonene $(5.1 \%)$ and $\beta$-pinene (5.0\%) (Höferl et al., 2014). Chanotiya and Mathela (2007) reported the essential oils composition from the leaves, berries and twigs of J. wallichiana. The essential oil from the leaves mainly contained sabinene $(46.7 \%), \alpha$-pinene $(6.6 \%)$ and terpinen-4-ol (6.5\%). Further, the berry essential oil contained higher content of sabinene $(50.6 \%)$ and $\alpha$-pinene $(8.1 \%)$ and the twig essential oil contained $\alpha$-cadinol (9.8\%), terpinen-4-ol (8.4\%) and oplopanone $(8.0 \%)$. Based on the previous studies, it was observed that the sabinene or $\alpha$-pinene is the most abundant component in the essential oil from the berries of different Juniperus species. On the contrary, the results of the present study revealed that the essential oil from the berries of J. chinensis was mainly dominated by terpinen-4-ol (31.10\%). All these studies evidenced a considerable qualitative and quantitative difference in the composition of the essential oils within the same species. In general, the variations in the essential oil composition and its contents are influenced by various factors such as plant's geographical region, age of the plant, collection time and weather parameters (temperature, relative humidity, sunshine hours and precipitations) (Rajabi et al., 2014; Dhouioui et al., 2016). It is common to find variation in the essential oil composition in different organs of the same plant. The essential oils are biosynthesized and stored in specialized structures called secretory glandules (glandular trichomes). They widely vary in their morphology, structure, function, and distribution among the plant organs. The development of secretory glands and their essential oil production appears to be regulated by genetic and environmental factors. So, the secretory structures may play a major role in the variation of essential oil composition between different plant organs (Boukhris et al., 2013; El Asbahani et al., 2015).

\section{CONCLUSIONS}

The present study revealed that the essential oils obtained from the needles, twigs and berries of J. chinensis are rich in monoterpenes including monoterpene hydrocarbons and oxygenated monoterpenes. A comparison of oils from different parts revealed the variation in the amounts of several constituents, especially in the monoterpene components. The findings of the present study could be useful for further research in connection with the isolation of essential oil components.

\section{ACKNOWLEDGEMENTS}

This study was supported by 2014 Research Grant from Kangwon National University. Dr. Kandhasamy Sowndhararajan was financially supported by the Agriculture and Life sciences Research Institute, Kangwon National University, Chuncheon 24341, Gangwon, Republic of Korea.

\section{REFERENCES}

Adams RP. 2007. Identification of essential oil components by gas Chromatography / mass spectrometry. Carol Stream, IL, USA: Allured Publishing Co.

Afsharypuora S, Rahiminezhad M, Ghaemmaghami L, Soleimani M, Khanmohammadi M, Afsharipour N. Essential oil constituents of leaves of the male and female shrubs of Juniperus chinensis L. from Isfahan. Iran J Pharm Sci,2007;3: 177-180.

Ali AM, Mackeen MM, Intan-Safinar I, Hamid M, Lajis NH, elSharkawy SH, et al.Antitumour-promoting and antitumour activities of the crude extract from the leaves of Juniperus chinensis. J. Ethnopharmacol, 1996; 53: 165-169.

Angioni A, Barra A, Russo MT, Coroneo V, Dessi S, Cabras P. Chemical composition of the essential oils of Juniperus from ripe and unripe berries and leaves and their antimicrobial activity. J Agric Food Chem, 2003; 51: 3073-3078.

Boukhris M, Nasri-Ayachi MB, Mezghani I, Bouaziz M, Boukhris M, Sayadi S.Trichomes morphology, structure and essential oils of Pelargonium graveolensL'Hér. (Geraniaceae).Ind CropProd, 2013; 50: 604-610

Butkiene R, Nivinskiene O, Mockute D, Miliute A. Variety of the essential oils composition of wood, needles (leaves), unripe and ripe 
berries of Juniperus communis var. communis growing wild in Druskininkai district. Chemija,2007; 18: 35-40.

Carroll JF, Tabanca N, Kramer M, Elejalde NM, Wedge DE, Bernier U.R, et al. Essential oils of Cupressus funebris, Juniperus communis, and J. chinensis (Cupressaceae) as repellents against ticks (Acari: Ixodidae) and mosquitoes (Diptera: Culicidae) and as toxicants against mosquitoes. J Vector Ecol,2011; 36: 258-268.

Chanotiya CS, Mathela CS. Essential oil composition of Juniperus wallichiana from north western region of Kumaun Himalaya. J Essent Oil Res, 2007; 19: 422-425.

Chen N, Sun G, Yuan X, Hou J, Wu Q, Soromou LW, et al. Inhibition of lung inflammatory responses by bornyl acetate is correlated with regulation of myeloperoxidase activity. J Surg Res, 2014; 186: 436445 .

Crowell PL, Gould MN.Chemoprevention and therapy of cancer by D-limonene.Crit Rev Oncog,1994; 5: 1-22.

Dhouioui M, Boulila A, Chaabane H, Zina MS, Casabianca H. Seasonal changes in essential oil composition of Aristolochia longa L. ssp. Paucinervis Batt. (Aristolochiaceae) roots and its antimicrobial activity. Ind Crop Prod, 2016; 83: 301-306.

El Asbahani A, Miladi K, Badri W, Sala M, AitAddi EH, Casabianca H, et al. Essential Oils: From Extraction to Encapsulation. Int J Pharm, 2015;483: 220-243.

Foudil-Cherif Y, Yassaa N.Enantiomeric and non-enantiomeric monoterpenes of Juniperus communis L. and Juniperus oxycedrus needles and berries determined by HS-SPME and enantioselective GC/MS. Food Chem, 2012;135: 1796-1800.

Hafi ML, Cazier F, Aboukais A, Jocelyne B, Beyrouthy ME. Chemical composition of the essential oils from (berries, leaves and twigs) of Juniperus excelsa M. Bieb. growing wild in Lebanon. . J Essent Oil Bear Pl, 2015; 18: 844-851.

Hart PH, Brand C, Carson CF, Riley TV, Prager RH, FinlayJones JJ. Terpinen-4-ol, the main component of the essential oil of Melaleuca alternifolia (tea tree oil), suppresses inflammatory mediator production by activated human monocytes. Inflamm Res, 2000;49:619626

Heuberger E, Hongratanaworakit T, Bohm, C, Weber R, Buchbauer G. Effect of chiral fragrances in human autonomic nervous system parameters and self evaluation, Chem Senses, 2001; 26: 281-292.

Höferl M, Stoilova I, Schmidt E, Wanner J, Jirovetz L, Trifonova $\mathrm{D}$, et al. Chemical composition and antioxidant properties of juniper berry (Juniperus communis L.) essential oil. Action of the essential oil on the antioxidant protection of Saccharomyces cerevisiae model organism. Antioxidants, 2014;3: 81-98.

Jin KS, Lee JY, Hyun SK, Kim BW, Kwon HJ. Juniperus chinensis and the functional compounds, cedrol and widdrol, ameliorate $\alpha$ melanocyte stimulating hormone-induced melanin formation in B16F10 cells. Food SciBiotechnol, 2015; 24: 611-618.

$\mathrm{Ju}$ JB, Kim JS, Choi CW, Lee HK, Oh TK, Kim SC. Comparison between ethanolic and aqueous extracts from Chinese juniper berries for hypoglycaemic and hypolipidemic effects in alloxan induced diabetic rats. JEthnopharmacol,2008; 115: 110-115.

Kim MG, Lee NH, Kim JM, Lee SG, Lee HS. Chemical composition of essential oils extracted from five Juniperus chinensis varieties in Korea. J Essent Oil Bear Pl,2015; 18: 852-856.

Kim SJ, Jung JY, Kim HW, Park T. Anti-obesity effects of Juniperus chinensis extract are associated with increased AMP activated protein kinase expression and phosphorylation in the visceral adipose tissue of rats. Biol Pharm Bull, 2008; 31: 1415-1421.
Kohzaki K, Gomi K, Yamasaki-Kokudo Y, Ozawa R, Takabayashi J, Akimitsu K. Characterization of a sabinene synthase gene from rough lemon (Citrus jambhiri). J Plant Physiol, 2009; 166: 17001704 .

Lee CH, Park JM, Song HY, Jeon EY, Lee HS.Acaricidal activities of major constituents of essential oil of Juniperus chinensis leaves against house dust and stored food mites. J Food Protect,2009; 72: 1686-1691.

Lim JP, Song YC, Kim JW, Ku CH, Eun JS, Leem KH, et al. Free radical scavengers from the heartwood of Juniperus chinensis. Arch Pharm Res, 2002;25: 449-452.

Lima NG, De Sousa DP, Pimenta FC, Alves MF, De Souza FS, Macedo RO, et al. Anxiolytic-like activity and GC-MS analysis of (R)(+)-limonene fragrance, a natural compound found in foods and plants.PharmacolBiochemBehav, 2013; 103: 450-454.

Loughlin R, Gilmore BF, McCarron PA, Tunney MM Comparison of the cidal activity of tea tree oil and terpinen-4-ol against clinical bacterial skin isolates and human fibroblastcells. Lett Appl Microbiol, 2008;46:428-433.

Maia-Joca RP, Joca HC, Ribeiro FJ, do Nascimento RV, SilvaAlves KS, Cruz JS, et al. Investigation of terpinen-4-ol effects on vascular smooth muscle relaxation. Life Sci, 2014; 115: 52-58.

Orav A, Koel M, Kailas T, Muurisepp M. Comparative analysis of the composition of essential oils and supercritical carbon dioxide extracts from the berries and needles of Estonian juniper (Juniperus communis L.). Procedia Chem, 2010;2: 161-167.

Pinheiro MA, Magalhães RM, Torres DM, Cavalcante RC, Mota FS, Oliveira Coelho EM, et al. Gastroprotective effect of alphapinene and its correlation with antiulcerogenic activity of essential oils obtained from Hyptis species. Pharmacogn Mag. 2015; 11: 123-130.

Raina VK, Srivastava SK, Syamsundar KV. Essential oil composition of Juniperus chinensis from the plains of northern India.Flavour Frag J, 2005; 20: 57-59.

Rajabi Z, Ebrahimi M, Farajpour M, Mirza M, Ramshini H. Compositions and yield variation of essential oils among and within nine Salvia species from various areas of Iran. Ind Crop Prod, 2014; 61: 233 239.

Sowndhararajan K, Cho H, Yu B, Kim S. Effect of olfactory stimulation of isomeric aroma compounds,(+)-limonene and terpinolene on human electroencephalographic activity. Eur J Integr Med, 2015; 7:561-566

Valente J, Zuzarte M, Gonçalves MJ, Lopes MC, Cavaleiro C, Salgueiro L, et al. Antifungal, antioxidant and anti-inflammatory activities of Oenanthe crocata L. essential oil. Food Chem Toxicol, 2013; 62: 349354.

Wang X, Ma A, Shi W, Geng M, Zhong X, Zhao Y. Quercetin and bornyl acetate regulate t-lymphocyte subsets and INF-y/IL-4 ratio in utero in pregnant mice. Evid Based Complement Alternat Med 2011; 2011: 745262

\section{How to cite this article:}

Sowndhararajan K, Seo M, Kim S. Comparative analysis of the composition of essential oils from the needles, twigs and berries of Juniperus chinensis L. in Korea. J App Pharm Sci, 2016; 6 (08): $122-126$. 